АРДАЕВА Наталия Вадимовна - доцент кафедры романских языков; почетный профессор Дипломатической академии МИД России (119992, Россия, г. Москва, ул. Остоженка, 53/2; kafedra. romjaz@dipacademy.ru)

\title{
ДИПЛОМАТИЧЕСКИЙ И ПОЛИТИЧЕСКИЙ ДИСКУРС. ЛАТИНСКАЯ АМЕРИКА
}

Аннотация. В статье автор рассматривает дипломатический и политический дискурс, национальные особенности латиноамериканского дискурса, личности наиболее ярких политических деятелей континента, а также дискурсионную специфику выступлений Фиделя Кастро.

Ключевые слова: дипломатический и политический дискурс, коммуникативная деятельность, Латинская Америка, дипломатическая служба

$\Pi$ олитический и дипломатический дискурс представляет собой особую форму коммуникативной деятельности, способствующую осуществлению целей и задач внешней и внутренней политики государств.

Поскольку в настоящее время не существует единого документа об обязательном языке дипломатического и политического дискурса, эта тема является объектом междисциплинарного изучения и анализа в области философии, политологии и социологии. Тема, будучи очень актуальной и объемной, скорее может быть рассмотрена в диссертационном поле, а не в форме статьи или доклада.

Политический и дипломатический дискурс, кроме публичного формата, может иметь другие формы внутриведомственной и международной коммуникативной деятельности, такие как межведомственная документация; заключение договоров; переписка; отношения со СМИ (коммюнике, официальные заявления и пр.); ведение переговоров.

На современном этапе развития международных отношений совершенно очевидно смещение их влияния и значимости в сторону публичного дискурса в системе международной коммуникации.

В этом формате политический и дипломатический дискурс имеет массу совпадений, общих задач и методов их реализации.

Границы и формат публичного дискурса расширяются в сфере дипломатической коммуникации для формирования общественного мнения, влияния на сознание и взгляды общества и донесения информации, необходимой для достижения изначально поставленной цели, продвижения новых идей.

По определению О.А. Курчаткиной, «политический дискурс - это актуальное использование языка в социально-политической сфере общения» [Курчаткина 2010: 24]. В связи с этим исключительную важность приобретает адекватный перевод документальных и публичных форм дискурса, который требует профессионализма, высокого уровня лингвистической подготовки, а также владения принципами перевода международного дискурса. Обязательным принципом перевода являются дискурсионные характеристики.

Языком дискурса является государственный язык страны при условии осуществления перевода на язык страны адресата или на один из официальных языков Организации Объединенных Наций.

На сферу дипломатической деятельности влияют вспомогательные формы международной коммуникации, такие как:

- сотрудничество в области экономических связей;

- культурный обмен;

- пресса; 
- международные и внутренние экономические проблемы, включая состояние кризиса;

- военные противостояния;

- личностные характеристики дипломатов и политиков.

Для решения международных и внутренних проблем вот уже несколько веков существует дипломатическая служба в России, странах Нового Света и Евразии.

Хорошо известны имена выдающихся дипломатов и политиков, игравших значительную роль в решении мировых проблем.

Если говорить о современных политических деятелях, лучшим примером является президент Российской Федерации В.В. Путин. Характерными чертами выступлений президента являются твердость, информированность, последовательность в отстаивании своих позиций, четкость, лаконичность, умение идти на компромиссы, если это не противоречит изначальной цели, умение отстаивать интересы государства.

Достаточно вспомнить выступление В.В. Путина в феврале 2007 г. в Мюнхене на конференции по международной безопасности, которое 10 лет назад перевернуло представление мировой общественности о России, определило позицию государства по вопросам международной политики первостепенной важности; именно там были расставлены приоритеты и ценности, предложены решения по ключевым вопросам.

Также нельзя недооценить колоссальный повседневный и результативный труд министра иностранных дел России С.В. Лаврова в деле налаживания международных отношений, урегулирования конфликтных ситуаций, влияния на решение важнейших вопросов в условиях кризиса международных отношений, информационной войны и вооруженных конфликтов на Ближнем Востоке.

Что касается Латинской Америки, дипломатическая служба в странах этого континента является достаточно молодой. Становление ее относится к середине XIX в. Она развивалась на уже существующей базе, но со своими особенностями, этническими акцентами, традициями, культурными ценностями. В дипломатии этих стран есть много самобытного, нового, вызывающего уважение и интерес.

Латинская Америка насчитывает более 30 государств с населением около 400 млн чел. Эти страны считались сателлитами, колониями Соединенных Штатов Америки, Испании, а потому не имели собственной дипслужбы.

C XIX в. начинается создание институтов по подготовке дипломатических кадров. Раньше немногочисленная дипломатическая элита этих стран получала образование, как правило, в странах Европы (во Франции, в Италии и др.), впоследствии - в СССР (если речь идет о Кубе), США.

В учебных заведениях Латинской Америки поддерживается американский принцип формирования этой элиты, т.е. преподавателями в них являются послы и другие дипломаты высокого ранга в отставке.

В становлении дипломатической службы в странах Латинской Америки активную роль играют Бразилия и Аргентина. Фундаментальная подготовка дипломатов - задача института Рио Бранко в системе МИДа Бразилии.

В 1928 г. была принята Гаванская конвенция о дипломатических чиновниках. В 1930 г. Х. Эстрада разработал доктрину о признании новых правительств. В 1984 г. открывается Дипломатическая академия в Лиме. Там же в 1996 г. проводится общая сессия Организации американских государств (ОАГ).

Если говорить об известных политических деятелях, Латинская Америка, начиная с начала XIX в., изобилует ярчайшими именами.

Это José Antonio Simón de Bolivar y Ponte (1783-1830) - венесуэльский патриот, государственный деятель, полководец, руководитель войны за независимость 
испанских колоний в Америке, одержавший ряд блистательных побед. В 1826 г. он создал Панамский конгресс, был близок к осуществлению своих планов, но не добился результата. Его огромная заслуга заключается в том, что именно он заронил искру борьбы за независимость. Именно к середине XIX в. относится начало формирования дипломатической службы в Латинской Америке.

José Martí (1853-1895) - лидер освободительного движения Кубы.

Многие латиноамериканские политические лидеры оставили яркий след в новейшей истории континента.

Juan Domingo Perón - дважды президент Аргентины (1946-1955, 1973-1974). Он и Eva Perón внесли свой вклад в развитие и влияние публичного дискурса.

Salvador Allende - президент Чили (1908-1973), погибший во время государственного переворота.

Ernesto Che Guevara (1928-1967) - руководитель партизанского движения, трибун кубинской революции.

Oscar Arias Sanchez (1940) - политик, дипломат, лауреат Нобелевской премии за миротворческую деятельность в 1987 г.

Hugo Chavez (1954-2013) - президент Венесуэлы.

Evo Morales Ayma - президент Боливии, индеец по происхождению.

Fidel Alejandro Castro Ruz, (1926-2016) - лидер кубинской революции, команданте (1959-2008).

М.В. Гордеева в своей статье, посвященной кубинскому лидеру, пишет: «Кубинская революция - одно из величайших исторических событий, повлиявших на умы всего мира. Как Кубе удалось всего за полвека не только построить действенную социалистическую модель общества, но и заставить весь мир обратить на себя внимание?

Первой и главной особенностью системы пропаганды на Кубе мы считаем личность Фиделя Кастро как народного трибуна» [Гордеева 2011: 1].

Политик колоссального масштаба, он является фигурой полемической и неоднозначной. Однако в качестве оратора, пропагандиста, народного трибуна ему нет равных.

Политический и дипломатический дискурс Латинской Америки характеризуется эмоциональностью, энергетикой, экспрессивностью. Стратег кубинской политики, основатель государства и военачальник, Ф. Кастро владел всеми этими качествами в максимальной степени.

Вопросы невероятного успеха Ф. Кастро, его международного авторитета, магического психологического воздействия на формирование общественного мнения его многочасовых выступлений являются предметом изучения специалистов, которые выделяют ряд приемов, обеспечивающих эффективность речи команданте: это контакт, диалог со слушателями; метафоры; сравнения; агитация; антитезы; риторические вопросы; дискредитация оппонентов.

Одним из первых публичных выступлений является программное выступление Фиделя Кастро в суде, получившее название «История меня оправдает». Даже покинув должность главы правительства Кубы, Фидель Кастро продолжал излагать свои идеи в рубрике «Размышления» в главном печатном органе Кубы Granma.

В этом уникальном успехе главную роль играют личность Фиделя Кастро, его фантастическая энергетика, харизма, органика его выступлений, что не только производит ошеломляющий эффект, но и меняет сознание общества и влияет на ход политических событий.

Мне довелось во время первой длительной командировки на Кубу в качестве инокорреспондента в торгпредстве СССР в Гаване получить кассету (к сожалению, утраченную) с записью блестящей речи Ф. Кастро на Playa Girón 
в момент попытки так называемой контрреволюции восстановить прежний режим в 1961 г., что в то время было вполне реально. Сохранить революционные достижения практически не было никаких шансов, но, как представляется, все решила многочасовая, фантастическая по силе воздействия речь революционного лидера.

Подводя итог, следует еще раз подчеркнуть, насколько велика и значима роль политического и дипломатического дискурса в решении разного рода вопросов, как внутренних, так и внешних, отстаивании интересов государства и общества, становлении, развитии и урегулировании международных отношений.

\section{Список литературы}

Курчаткина О.А. 2010. Некоторые аспекты национально-культурной специфики латиноамериканского политического дискурса. - Вестник Московского государственного лингвистического университета. Сер. Языкознание. Вып. 10(589). С. 22-32.

Гордеева М.В. 2011. Особенности кубинской пропаганды. Роль Фиделя Кастро в становлении кубинской пропаганды. - Материалы международного молодежного научного форума «ЛОМОНОСОВ-2011» (отв. ред. А.И. Андреев, А.В. Андриянов, Е.А. Антипов, М.В. Чистякова). М.: МАКС Пресс. Доступ: https://lomonosov-msu.ru/archive/Lomonosov_2011/structure_9_1213.htm; https://lomonosov-msu.ru/archive/Lomonosov_2011/1213/2290_a9ec.p̄ōf

\section{DIPLOMATIC AND POLITICAL DISCOURSE. LATIN AMERICA}

Abstract. The article deals with diplomatic and political discourse. The author pays special attention to the national characteristics of Latin American political discourse. The variety of styles is studied by the example of speeches of Fidel Castro.

Keywords: diplomatic and political discourse, communicative activity, Latin America, diplomatic service 